\title{
INDUSTRIAL APPLICATION OF CHITOSAN AS PROMISING MATERIAL FOR WASTEWATER PURIFICATION: A REVIEW
}

\author{
Belgis $^{1 *}$ \\ ${ }^{1}$ Department of Vocational Study Universitas Airlangga, 60286, Indonesia
}

(Received: December 2019 / Revised: December 2019 / Accepted: January 2020)

\begin{abstract}
The rapid growth of the industry is giving positive effects for humans by providing daily needs and supporting economic development. However, the industrial process also releases pollution to the environment, which can cause water scarcity, biodiversity loss, and climate change. Removing these pollutants from various industrial wastes is a requirement for ensuring proper water quality for human consumption, agricultural use, and environmental safety. This work aims to explain the use of natural resources as a source of valuable compounds that can be used in wastewater treatment, particularly in Indonesia, by adopting a literature study method reviewing both national and international references. Chitosan is an effective bio-absorbent pollutant because of its high level of deacetylation and free amino groups, making it polycationic which is capable of being bound to metals, proteins, and dyes. Chitosan membranes can be applied only with chitosan material and composites: chitosan-Polyethylene Glycol (PEG), chitosan-Poly Vinyl Alcohol, chitosan-biosilica, chitosan-PVA-silica, chitosan-alginate, chitosan-cellulose, and chitosan-silica. Chitosan has the ability as a coagulant and reducing water turbidity. Chitosan can absorb metal ion ( $\mathrm{Cr}$ (VI), $\mathrm{Cs}+, \mathrm{Pb}(\mathrm{II}), \mathrm{Fe}, \mathrm{Cu}(\mathrm{II})$ ), dyes (anthraquinone dyes, brilliant blue, yellow dye, methylene blue, disperse orange, disperse blue, rhodamine B), drug residue, and hazardous materials, and can be used as raw material or in a film form. Since there is a high abundance of chitosan raw material in Indonesia, it is supposed to be able to support the application of chitosan as a natural purifying agent considering its high ability to absorb heavy metal and some dangerous materials.
\end{abstract}

Keywords: adsorbent; chitosan; membrane; wastewater

\section{INTRODUCTION}

The rapid development of the industry plays a vital role in economic growth since it denotes an indicator of the positive growth of the country. However, industrial growth also harms our environment because the residue from the industrial production process is dangerous. Pollution released by the industrial process releases to the environment can cause water scarcity, biodiversity loss, and climate change. The disposal of unsafe industrial and municipal wastewater containing various chemicals such as solvents, dyes/paints, pesticides, and medicines, can harm the river systems. The release of untreated dye waste, which also contains organic matter, metals, bleach, and salt, not only changes the physicochemical parameters of surfaces and groundwater bodies but also adversely affects aquatic and human life (Markandeya et al., 2017).

The sewage sludge that accumulates at the wastewater treatment center is a mixture of various

*Corresponding author's email: belgis@vokasi.unair.ac.id

DOI: https://doi.org/10.32783/csid-jid.v3i1.92 
organic and inorganic materials containing substances and microorganisms from various sources (Bratina et al., 2016). The composition of liquid waste consists of $99.9 \%$ water, and the rest is solid material (Lessa et al., 2018). The final waste from the industrial process is discharged into the waters and rivers after passing through wastewater management. Some industries do not have standard waste disposal; hence they cause water pollution in river areas (Karimifard \& Alavi Moghaddam, 2018; Li et al., 2019). The problem of waste must be overcome in order to be corresponding to the environmental sustainability issue, particularly in wastewater treatment, in which only hygienic material can be released into the environment. At present, the technology for the separation and recovery of water purification using organic materials has progressed, is easily accessible, and is generally inexpensive. Liquid waste is released as a suspension or granules in liquid media (Li et al., 2019).

Various waste management methods are being used to separate the pollution of liquid waste in physical, chemical, and biological forms from waste treatment or in combination. In general, chemical wastewater treatment is a separation process with a coagulation-flocculation system (Karimifard \& Alavi Moghaddam, 2018). Some chemicals can be used efficiently and effectively but still somehow produce other residues that contain hazardous substances. Providing an effective, efficient, and harmless liquid waste management system is an effort to minimize pollution residues on water. One of the wastewater treatment technologies that are widely used today is membrane technology. The current use of membranes can be carried out on a large scale to produce drinking water from seawater in the desalination process by reverse osmosis, constituent recovery by electrodialysis, fractionation of macromolecules in the food and beverage industry by ultrafiltration processes and removing poisons and other poisons from human blood by dialysis in artificial kidneys (Karimifard \& Alavi Moghaddam, 2018). Chitosan is a cationic polymer that is non-toxic, biodegradable, and biocompatible. Chitosan is an effective bioabsorbent pollutant because of its high level of deacetylation and free amino groups, so it is polycationic which is capable of binding to metals, proteins, and dyes. However, chitosan also has weaknesses. The use of chitosan as bio-absorbent dissolves in low $\mathrm{pH}$ so that it cannot absorb $\mathrm{Cr}$ (III) at low pH (Al-Manhel et al., 2018). This is caused by the active site (amine group) of chitosan that undergoes protonation, and the adsorption ability is influenced by anions in the waters.

Previous experiments have examined biopolymers that can bind heavy metal waste through the formation of complex compounds so that biopolymers can act as adsorbents to separate heavy metals from water even in deficient concentrations. One of the potential biopolymers as heavy metal adsorbents from wastewater is chitosan, the research of which has been extensively conducted for these last 25 years (Al-Manhel et al., 2018). Currently, chitosan has been widely used in industry as the absorbent of heavy metals in the water purification process, a preservative and anti-cholesterol in the food industry, a fertilizer factory, for cosmetics, and a surface coating for photo paper (Ma et al., 2018).

In Indonesia, chitosan has been researched for its application to enhance water quality (Ruswahyuni Hartoko, Agus, 2010). The experiments have been done to optimize the function of chitosan for purifying wastewater, but only a few industries have applied it to their waste management, despite it being in high abundance in Indonesia (Arifin et al., 2017; Noralia \& Dina Kartika, 2013; Utami, Umi Barorh Lili Irawati, Utami, 2011). The increasing demand for safe drinking water, particularly in developing and underdeveloped countries, is a serious challenge because the sources of clean water available are epidemically polluted. Therefore, removing these pollutants from various industrial wastes, before being discharged into water bodies, is a requirement for ensuring proper water quality for human consumption, agricultural use, and environmental safety (Nurdjannah, 2016). 
In this context, this paper aims to explain the use of natural resources as a source of valuable compounds that can be used in wastewater treatment. This technology can not only solve the problem of environmental pollution caused by industrial residues but also identify alternative natural resources that can be used optimally. Future research opportunities are shown for extensive use to minimize harmful environmental impacts.

\section{LITERATURE STUDY}

Chitosan is a 2-amino-2-deoxy-D-glucose polymer with $\beta$-1,4-glycoside bonds. Naturally, chitosan contains acetyl groups in some of its monosaccharides. The physical and chemical characteristics of chitosan are white and crystalline, soluble in organic acid solutions, but not soluble in other organic solvents. High-grade chitosan dissolves in acetic acid. Chitosan is slightly soluble in water, slightly dissolvable in $\mathrm{HCl}$ and $\mathrm{HNO}_{3}, 0.5 \% \mathrm{H}_{3} \mathrm{PO}_{4}$, whereas in $\mathrm{H}_{2} \mathrm{SO}_{4}$, it is not soluble. Chitosan has a strong positive charge, which can bind the negative charge of other compounds, and is easily subjected to biological degradation. The viscosity of chitosan in acetic acid tends to increase with increasing acid concentration or decreasing $\mathrm{pH}$ (Al-Manhel et al. 2018). Polymers obtained from renewable resources or valorization of agro-industrial and marine waste and by-products are considered attractive alternatives. Crustacean shell waste is the most abundant source of Chitin, but also the most available source to support commercial production of chitosan.

Chitosan is one of the most abundant organic materials after the amount of cellulose produced every year through the biosynthesis process, in which Chitin is its raw material. This is an essential constituent of the exoskeleton in animals, especially in crustaceans, mollusks, and insects. It is also the primary fibrillar polymer in particular fungal cell walls (Yavuz et al., 2009). The glucosamine content in chitosan is called the degree of deacetylation (DD). Depending on the source and preparation procedure, the molecular weight can range from 300 to more than $1,000 \mathrm{kD}$ with DD from $30 \%$ to $95 \%$ (Kumari et al., 2015; Kumari \& Rath, 2014). In general, chitosan has three types of reactive functional groups, amino groups, and primary and secondary hydroxyl groups, respectively in positions C (2), C (3), and C (6). These groups allow chitosan modifications such as graft copolymerization for specific applications, which can produce a variety of scaffolds that are useful for tissue engineering applications. The chemical properties of chitosan, in turn, provide many possibilities for a covalent and ionic modification that allow extensive adjustment of mechanical and biological properties. Chitosan is a natural material that has very high economic value and use-value. The use of chitosan as a material to purify liquid waste, especially industrial waste, needs to be increased, given the high impact resulting from disposed of liquid waste that is not appropriately refined. The advantage of chitosan as an easily formed and easily obtainable material is the opportunity for researchers to experiment and create the right formula to overcome the problem of liquid waste.

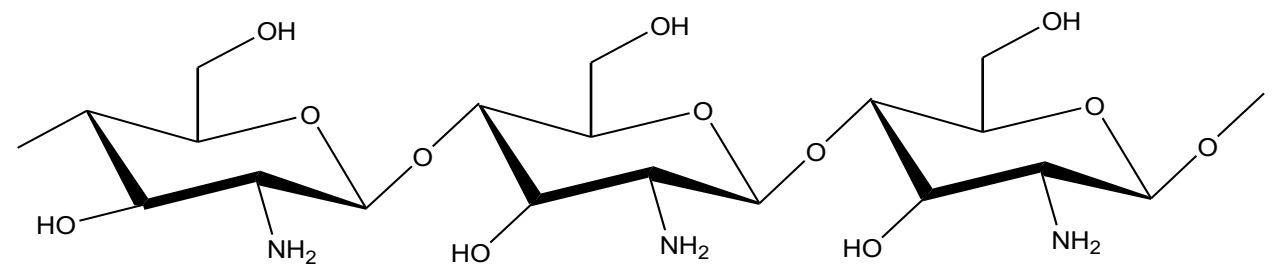

Figure 1 Chemical structure of Chitosan

\section{METHODS}

This study is conducted using literature study methods. The national references gathered from 
google scholar (30\%) and international references (70\%) gathered from ScienceDirect and Scopus resources. The review performed in the thematical section, where each topic or issue was organized by theme approach and discussion. A similar issue will be summarized within each thematic section and illustrated comprehensively.

\section{RESULTS AND DISCUSSION}

\subsection{The Application of Chitosan}

\subsubsection{Filtrate membrane materials}

The chitosan membrane is a semi-permeable thin layer between two phases that has different characters. The first phase is the feeder solution, while the second phase is the permeate or separation results. The most important thing about membranes is the ability to control the size of particles that passing off through membranes. The chitosan membrane is often widely used for various separation processes because of the membrane properties and the ability. Chitosan membranes can absorb heavy and dangerous metal ions.

Chitosan membrane is made by dissolving chitosan in $0.75 \%$ acetic acid then stirring it using a stirrer for 3 hours to form a dope (clear thick liquid). Chitosan membrane can also be added with crosslinker compounds such as formaldehyde and glutaraldehyde, to enhance its bonding strength when it is further composited with other materials.

Chitosan membrane can be applied only with chitosan material (Ramadhanur \& Sari, 2015) and composites. Some chitosan composites include chitosan-Poly ethylene Glycol (PEG) (Wahyuni et al., 2017), chitosan-Poly Vinyl Alcohol (Wahyuni et al., 2017), chitosan-biosilica (Zulfi et al., 2014), chitosan-PVA-silica (Chodijah,Siti \& Liza,Novriani, 2018), chitosan-alginate (Evaani \& Cahyaningrum, 2012), chitosan-cellulose (Nurdin \& Maulana, 2016), and chitosan-silica (Noralia \& Dina Kartika, 2013).

\subsubsection{Coagulant materials}

Coagulation is the process of forming clots using coagulant material. Coagulation is also a colloidal clumping into a more substantial form. Sediments can be obtained from colloids by heating, so that larger particles develop and encourage smaller particles (Aulia et al., 2016). Particle size affects the deposition of particles in aqueous media. Colloids require coagulant substances to form deposits and also need sufficient time to settle ultimately. If the deposition time is less, then the suspended solids can be shifted so that coagulation and flocculation processes can occur so that the larger particle size and deposition occur quickly (Kumari \& Rath, 2014).

The use of coagulants in processing industrial waste has become a common thing to do. Coagulants reduce turbidity and bind solids in water (Fatombi et al., 2013). Chitosan has the ability as a coagulant and has the function of lowering wastewater pollution so that it becomes more apparent by $43 \%$ to $50.5 \%$ (Arifin et al., 2017; Susanto, Joko Prayitno, 2000; Utami, Umi Barorh Lili Irawati, Utami, 2011).

\subsubsection{Adsorbent materials}

Adsorbents are very porous materials, and the adsorption process occurs mainly in pore walls or specific areas in a particle. Adsorbents are considered as suitable adsorbents if the absorption and drying time is fast (Hameed et al., 2008). Contact time is crucial in the adsorption process. 
Adequate contact time allows the diffusion and adhesion process of absorbing molecules to take place better (Mohd Din et al., 2009; Yavuz et al., 2009).

As an adsorbent, chitosan can be applied alone or in combination with other suitable materials to increase its effectiveness. The function of chitosan as an adsorbent is to absorb harmful substances and colors (Hui et al., 2018; Markandeya et al., 2017; Nitayaphat, 2017; Nuralam, Endoraza \& Arbi, 2012; Shaida et al., 2018) that can be improved by using a combination of materials such as activated coconut shell charcoal, chitosan-silica bead (Susilowati, Endang \& Mahatmanti, 2018), chitosan-rubber (Phasuphan et al., 2019), chitosan- $\mathrm{Fe}_{3} \mathrm{O}_{4}$ salt (Liu et al., 2016), chitosan-epichlorohydrin (Yan et al., 2018), chitosan-carbon (Yong-hong Huang, 2018), and chitosan-lignin (Nair et al., 2014).

Pal et al. (2013) showed excellent adsorbent activity from a large number of chitosan gel beads. Its diverse biocompatibility makes bio gel beads more attractive. Chitosan hydrogel beads that have a synergistic effect play an essential role in increasing the efficiency of adsorption. Dyes materials that have been absorbed by chitosan hydrogel beads can be recovered quantitatively using acetone. This positively supports an environmentally friendly process that implements a 'zero waste' management strategy.

\subsection{Utilization of Chitosan for Purification Waste}

\subsubsection{Metal Ion Waste}

Metal-containing liquid waste is produced from several industrial activities such as oil mining at sea, liquid clothing dye residues, liquid preservative residues, moisture content metals, Tempe waste, tofu waste, and other chemical wastes (Al-Manhel et al., 2018).

A gel made from chitosan-multiwall carbon nanotube (MWNT)-poly(acrylic acid)-(PAA)poly(4-amino diphenylamine) (PADPA) can be used to remove hexavalent chromium (Cr (acrylic acid) (PAA)-poly(4-amino diphenylamine) (PADPA) by eliminating hexavalent chromium (Cr(VI)) (Kim et al., 2015).

Chitosan-alkali lignin composites can be used to eliminate the harmful effects present in potential wastewater from the paper industry and the bioreactors today (Nair et al., 2014). Studies demonstrated that chitosan-alkali lignin composites (50:50) show the maximum percentage removal of $\mathrm{Cr}(\mathrm{VI})$ compared to other composites.

A simple polymer crosslinking method can be used to remove anionic $\mathrm{Cr}(\mathrm{VI})$ compounds efficiently and quickly through adsorption in liquids (Yimin Huang et al., 2018). Modifications to carboxylated multi-wall carbon nanotubes (MWCNTs-COOH) with chitosan were carried out to increase the adsorption of $\mathrm{Cr}(\mathrm{VI})$ in acidic solutions. Chitosan/MWCNTs-COOH composites were proved to be successfully applied in several $\mathrm{Cr}(\mathrm{VI})$ adsorption cycles, without limited performance loss (98-100\% adsorption until the 4th cycle).

Chitosan obtained from seafood processing waste (shrimp shells) and characterized physicochemically was used in a study, in which it is then synthesized using tripolyphosphate (Dima et al., 2015). The synthesis results were then tested for the ability to remove hexavalent chromium $\mathrm{Cr}(\mathrm{VI})$ from contaminated water, at different initial chromium concentrations. Chemical analysis carried out showed that the $\mathrm{Cr}(\mathrm{VI})$ removed from the solution was bound to chitosan as $\mathrm{Cr}$ (III). The conversion of toxic $\mathrm{Cr}$ (VI) to less (or non-toxic) $\mathrm{Cr}$ (III) by micro-chitosan / reticulated nanoparticles can be considered as a very efficient detoxification technique for treating $\mathrm{Cr}(\mathrm{VI})$ contaminated water. 
A novel chitosan- $\mathrm{Al}_{2} \mathrm{O}_{3}-\mathrm{SiO}_{2}$ hybrid composite was used and applied to remove hexavalent chromium $[\mathrm{Cr}(\mathrm{VI})]$ from the liquid, the condition of which was in the acidic $\mathrm{pH}$ range hence it was conducive to $\mathrm{Cr}$ (VI) adsorption (Zhang et al. 2018). It only took ten minutes to achieve $80 \%$ adsorption activity. Furthermore, the adsorption ability of this material does not decrease even after five usage cycles.

In another study, Magnetic bentonite-chitosan hybrid beads (Bn-CTS) that were easily obtained and made by immobilizing bentonite in the porous structure of chitosan beads was used to achieve the effect of hybrid adsorption as remover cesium, Ion $\left(\mathrm{Cs}^{+}\right)$from water (Wang et al., 2019). The adsorbent used has excellent selectivity to adsorbs $\mathrm{Cs}^{+}$in the presence of other cations $\left(\mathrm{Li}^{+}, \mathrm{Na}^{+}\right.$, $\mathrm{K}^{+}$, and $\mathrm{Mg}^{2+}$ ). It can be used again by immersing the beads with $0.1 \mathrm{~mol} \mathrm{~L}^{-1}$ of $\mathrm{MgCl}_{2}$ to absorb $\mathrm{Cs}+$ from the beads quantitatively. Bentonite-magnetic chitosan beads can be used as highly efficient adsorbents for the disposal and management of radioactive waste.

Magnetic composites $\mathrm{Fe}_{3} \mathrm{O}_{4}$-chitosan-bentonite $\left(\mathrm{Fe}_{3} \mathrm{O}_{4}\right.$-CS-BT), synthesized natural materials can be applied to restore acid mine drainage for the disposal of heavy metals, especially $\mathrm{Cr}(\mathrm{VI})$ in the fluid was examined (Feng et al., 2019). The findings of this study showed that $\mathrm{Fe}_{3} \mathrm{O}_{4}-\mathrm{CS}-$ BT composite could function optimally at $\mathrm{pH} 2.0$ and can be used repeatedly by adjusting the magnetic field. Its adsorption capacity was reduced by only $3 \%$ after five successive adsorption processes. Furthermore, $\mathrm{Fe}_{3} \mathrm{O}_{4}-\mathrm{CS}$-BT composite also has excellent adsorbent capabilities for AMD remediation containing $\mathrm{Cd}, \mathrm{Cr}, \mathrm{Cu}, \mathrm{Fe} \mathrm{Zn}, \mathrm{Ni}$, and $\mathrm{Pb}$.

Chitosan and its derivative modifications can be used to improve the adsorption properties of magnetic materials to remove $\mathrm{Pb}$ (II) metal ions (Zhang et al., 2018). The material used is a modification of chitosan- $\mathrm{Fe}_{3} \mathrm{O}_{4}$. The application of this material showed that the initial adsorption results of $\mathrm{Pb}$ (II) metal were rapid and equilibrium was achieved in 105 minutes. The maximum absorption capacity is $86.20 \mathrm{mg} / \mathrm{g}$ Chitosan- $\mathrm{Fe}_{3} \mathrm{O}_{4}$.

An adsorption technique can be used to eliminate hexavalent Chromium ( $\mathrm{Cr}(\mathrm{VI}))$ using chitosan grafted graphene oxide (CS-GO) nanocomposite in batches nanocomposite material was prepared using ultrasonic irradiation techniques (Samuel et al., 2019). The results of the CS-GO adsorbent nanocomposite were analyzed by X-ray (XRD), Fourier transforms infrared (FTIR) spectroscopy, scanning electron microscopy (SEM) and Tunneling electron microscopy (TEM), followed by $\mathrm{Cr}$ (VI) adsorption studies. The nanocomposite adsorption ability has an adsorption capacity of $104.16 \mathrm{mg} / \mathrm{g}$, which was achieved at an acidic $\mathrm{pH}$ of 2.0 , at a contact time of 420 minutes. It showed that CS-GO nanocomposite material could be used repeatedly for up to 10 cycles with a very minimum capacity reduction.

In another research, chitosan-grafted magnetic bentonite (CS-g-MB), which was synthesized through the plasma induction method, was investigated (Yang et al., 2016). The CS-g-MB composites showed good magnetic properties, low turbidity performance, and high stability in aqueous solutions, also indicated a significant adsorption capacity for $\mathrm{Cs}^{+}$ions. The ability of $\mathrm{Cs}^{+}$ adsorption by CS-g-MB depends on the $\mathrm{pH}$ atmosphere and ionic strength. For some $\mathrm{Mg}^{2+}, \mathrm{K}^{+}$, $\mathrm{Li}^{+}$, and $\mathrm{Na}^{+}$ions, the $\mathrm{Cs}^{+}$exchange is limited in the order of $\mathrm{Li}^{+} \approx \mathrm{Mg}^{2+}<\mathrm{Na}^{+}<\mathrm{K}^{+}$, especially as the hydration energy of these cations in aqueous solutions. CS-g-MB composite stability tests have been carried out in simulated groundwater media and actual seawater, and the results showed that increased coagulation could be achieved by modification of plasma for wastewater management. This adsorbent can also reduce the level of turbidity of water and can be used repeatedly.

According to Lasindrang, et al. (2015), activated coconut shell charcoal Chitosan is more effective in absorbing heavy metal $\mathrm{Cr}$ (total) at $\mathrm{pH} \mathrm{4,} \mathrm{more} \mathrm{effective} \mathrm{in} \mathrm{BOD} \mathrm{adsorption} \mathrm{at} \mathrm{pH} 6$, and has more influence on COD adsorption at $\mathrm{pH} 1$. The concentration of activated coconut shell charcoal coated with chitosan. The adsorbent $\mathrm{C}(\mathrm{K} 3 \mathrm{~A} 1)$ is the adsorption of $\mathrm{Cr}$ (total), BOD, and 
COD, which is more effective than adsorbent A (K1A1) and adsorbent B (K2A1) (Lasindrang et al., 2015).

Crosslinked chitosan/Waste Active Sludge Char (WASC) beads were developed as a novel composite adsorbent for the removal of $\mathrm{Cu}$ (II) ions from aqueous solution (Dandil et al., 2019). A study conducted using $\mathrm{Cu}(\mathrm{II})$ adsorbed from aqueous solutions quickly and efficiently by the xanthate $\mathrm{Fe}_{3} \mathrm{O}_{4}-\mathrm{CS}-\mathrm{GO}$ complex, suggested that xanthate $\mathrm{Fe}_{3} \mathrm{O}_{4}-\mathrm{CS}-\mathrm{GO}$ may be an ideal candidate for removing $\mathrm{Cu}$ (II) from wastewater (Liu et al., 2016). A summarized list of those aforementioned metal ion waste adsorbed by chitosan can be seen in Table 1 below.

Table 1 Metal ion waste adsorbed by chitosan

\begin{tabular}{cc}
\hline Metal ion & References \\
\hline Cr (VI) & (Dima et al., 2015; Feng et al., 2019; Yimin Huang et al., 2018; \\
& Kim et al., 2015; Lasindrang et al., 2015; Nair et al., 2014; \\
& $\begin{array}{c}\text { Noralia \& Dina Kartika, 2013; Samuel et al., 2019; Zhang et } \\
\text { al., 2018; Zulfi et al., 2014) }\end{array}$ \\
\hline $\mathbf{C s}^{+}$ & (Wang et al., 2019; Yang et al., 2016) \\
\hline Pb (II) & (Nuralam, Endoraza \& Arbi, 2012; Susilowati, Endang \& \\
& Mahatmanti, 2018; Utami, Umi Barorh Lili Irawati, Utami, \\
& 2011; Yan et al., 2018; Zhang et al., 2018) \\
\hline Fe & (Hui et al., 2018; Nuralam, Endoraza \& Arbi, 2012; Nurdin \& \\
& Maulana, 2016) \\
\hline Cu (II) & (Dandil et al., 2019; Liu et al., 2016; Susilowati, Endang \& \\
& Mahatmanti, 2018)
\end{tabular}

\subsubsection{Drug and Hazardous Material Waste}

Medicinal waste and hazardous substances are industrial waste that can have long-term adverse effects. This waste also causes environmental damage and endangers the health of the living population. A study by Ramadhanur et al. (2015) used chitosan as a membrane filtration of phosphate compounds in the detergent waste industry (Ramadhanur \& Sari, 2015), that can absorb phosphate residue up to $97.40 \%$. Another study used a membrane based on chitosan, PVA, and silica as a filter material for palm oil liquid waste that can reduce BOD levels up to $92.59 \%$, COD 92.59\%, and TDS 31.098\% (Chodijah, Siti \& Liza, Novriani, 2018). Meanwhile, this study indicated that bentonite-chitosan could be used as the removal of cesium radioactive elements in waste (Wang et al., 2019).

Composites that are made from coffee-grounds (WCG) waste combined with chitosan (Cs) and poly (vinyl alcohol) (PVA) was used in a study conducted by (Lessa et al., 2018). At 5\% by weight of WCG, the adsorption carried out by composites showed a marked increase (from 10 to $44 \%$ ) of the adsorption of drugs (metamizole (MET), acetylsalicylic acid (ASA), acetaminophen (ACE), and catalyst compared to samples pure. The highest transfer efficiency was listed at $\mathrm{pH}$ six, and the transfer followed the sequence ASA $>$ CAF $>$ ACE $>$ MET. Overall, WCG showed good interaction with polymer matrices and excellent dispersibility of up to $10 \%$ by weight. Experiments showed that composites containing WCG present extraordinary reusability in at least five successive adsorption/desorption cycles.

A coal-chitosan composite was used as an adsorbent to remove diethyl phthalate (DEP) through adsorption in a study by (Shaida et al., 2018). The coal used as coal with low carbon content and high silicate. This is also the use of low-quality coal waste. The 9: 1 weight ratio is the ratio that functions optimally from the coal-chitosan composite. This composition can absorb as much as 
91.1\% DEP under optimal conditions of $\mathrm{pH} 5.8$. The dose of adsorbent used is $4 \mathrm{mg} / \mathrm{mL}$, and the contact time required is 4 hours. The application of coal-chitosan composites as an adsorbent can be used easily and has been proven by repeated use.

Another research indicated that a modification of chitosan polymer could be used in used tire rubber as the removal of anti-inflammatory drugs ibuprofen, diclofenac, and naproxen from aqueous solutions. Modified capacity adsorbents were 70.0, 17.7, and $2.3 \mathrm{mg} / \mathrm{g}$, respectively, for ibuprofen, diclofenac, and naproxen. Various methods have been used to optimize the parameters that affect the efficiency of drug removal to obtain $\mathrm{pH} 6$ as the optimal $\mathrm{pH}$ to eliminate all three drugs simultaneously (Phasuphan et al., 2019).

\subsubsection{Dye Removal Waste}

The dye waste can cause problems because the low amount of color can be highly visible in water and may be toxic to aquatic organisms (Markandeya et al., 2017). The primary source of releasing color content to the environment is related to the imperfect use of dyes in the textile, food, leather, and paper industries. Waste of textile color content is a particular concern because textile consumption will always increase following population growth. Most dyes are made to have resistance to environmental influences such as the effects of $\mathrm{pH}$, temperature and microbial invasion; thus processing of color levels becomes difficult due to the aromatic structure of the dyes which is challenging to be biodegraded, primarily reactive dyes due to the formation of strong covalent bonds between the $\mathrm{C}$ atom of the dyestuff with the $\mathrm{O}, \mathrm{N}$ or $\mathrm{S}$ atoms of the hydroxy, amine or thiol groups of the polymer. Chitosan and iron precursor can be used as desorption of congo red for anionic dye wastewater (Hui et al., 2018).

Chitosan-alkali lignin composites can be used to eliminate the harmful effects present in wastewater. Batch adsorption studies showed that chitosan-alkali lignin composites (50:50) showed the maximum percentage removal of anthraquinones dyes, Remazol Brilliant Blue $\mathrm{R}$ (RBBR), and $\mathrm{Cr}(\mathrm{VI})$ compared to other composites, chitosan, and alkaline lignin. This can be used to utilize lignin residue, which is a potential waste by-product of the paper industry and biorefractory (Nair et al., 2014).

Chitosan fibers extracted from shrimp shells with high adsorption capacity were used in a study to remove acid yellow dyes from water. Under acidic conditions, the protonated amino groups (positively charged polymer chains), which show attraction with negative ions, are anionic dyes (Iqbal et al., 2011).

The study conducted by (Nitayaphat, 2017) utilized the adsorption of chitosan beads with a combination of coffee residue mixture to remove Reactive Red 152 as an anionic dye. The results showed that the mass ratio of chitosan to coffee residue 60/40 was the most useful for increasing dye removal. While a study by (Sohni et al., 2019) used the new chitosan / nano-lignin composite material as a highly efficient adsorbent $(\sim 83 \%)$ to remove methylene blue (MB) dyes. The adsorption mechanism carried out was one-color adsorption with a maximum adsorption capacity of $74.07 \mathrm{mg} \mathrm{g}^{-1}$. Chitosan composites with nano-lignin also showed better performance in dye decontamination compared to original chitosan and chitosan / bulk-lignin composites. These chitosan-nanolignin composites can be repeated in up to four cycles of adsorption/regeneration, with the results showing recovery as high as $89 \%$.

Two studies by Markandeya et al. conducted efficient, economical, and effective wastewater treatment based on the response surface methodology for removing dyes using cenosphere, waste products, in the form of nanocomposites with chitosan. Chitosan-cenospheres (10: 3) nanocomposite was synthesized using glutaraldehyde, a crosslinking agent, deposited in an alkaline solution to adsorb Disperse Orange 25 (DO) and Disperse Blue 79: 1 (DB). The 
maximum percentage of dyestuff removal found was $97.30 \%$ and $94.22 \%$ for DO and DB, respectively (Markandeya et al., 2017, 2018).

Chitosan-PVA composite membrane was used as a filter in waste of rhodamine B dye, in which the best membrane has a pore size of about $0.01-0.15 \mathrm{~mm}$ with $75 \%: 25 \%$ chitosan-PVA composition. The membrane can separate the waste of rhodamine B dye up to $87.029 \%$ (Novi et al., 2016). Another study (Lou et al., 2018) used a natural polymer-based flocculant that has attracted more attention, in which chitosan and lignin ingredients were mixed by microwaves. The flocculation study indicated that the chitosan-acrylamide-lignin polymer (CAML, 2 g: 2 g: 2 g) showed a maximum removal percentage of $99.3 \%$ and $67.0 \%$ respectively for $\mathrm{C}-3 \mathrm{R}$ reactive oranges and methyl oranges which reacted actively at acidic $\mathrm{pH}$.

\section{CONCLUSION}

Chitosan membranes which can only be applied with chitosan material and composites: chitosanPoly ethylene Glycol (PEG), chitosan-Poly Vinyl Alcohol, chitosan-biosilica, chitosan-PVAsilica, chitosan-alginate, chitosan-cellulose, and chitosan-silica, has the ability to be a coagulant and reduce water turbidity. Chitosan which is used as raw material or in a film form can also adsorb metal ion ( $\mathrm{Cr}(\mathrm{VI}), \mathrm{Cs}^{+}, \mathrm{Pb}(\mathrm{II}), \mathrm{Fe}, \mathrm{Cu}(\mathrm{II})$ ), dyes (anthraquinone dyes, brilliant blue, yellow dye, methylene blue, disperse orange, disperse blue, rhodamine B), drug residue, and hazardous materials. The high abundance of chitosan raw material in Indonesia should be able to support the application of chitosan as a natural purifying agent consider its high ability to adsorb heavy metal and some dangerous materials.

\section{ACKNOWLEDGMENT}

We would like to thank School of Vocational Faculty Universitas Airlangga for providing laboratory facility, funding, and the experiment resources for the researchers.

\section{REFERENCES}

Al-Manhel, A. J., Al-Hilphy, A. R. S., \& Niamah, A. K. (2018). Extraction of chitosan, characterisation and its use for water purification. Journal of the Saudi Society of Agricultural Sciences, 17(2), 186-190. https://doi.org/10.1016/j.jssas.2016.04.001

Arifin, A., Karlina, A., \& Khair, A. (2017). The Effect of Chitosan Dosage Against Liquid Waste Water Color on "Oriens Handicraft" Sasirangan Home Industry, Landasan Ulin. Journal of Health Science and Prevention, 1(2), 58-67. https://doi.org/10.29080/jhsp.v1i2.91

Aulia, Z., Sutrisno, E., \& Hadiwidodo, M. (2016). Pemanfaatan Limbah Cangkang Kepiting Sebagai Biokoagulan Untuk Menurunkan Parameter Pencemar Cod Dan Tss Pada Limbah Industri Tahu. Jurnal Teknik Lingkungan, 5(2), 12.

Bratina, B., Šorgo, A., Kramberger, J., Ajdnik, U., Zemljič, L. F., Ekart, J., \& Šafarič, R. (2016). From municipal/industrial wastewater sludge and FOG to fertilizer: A proposal for economic sustainable sludge management. Journal of Environmental Management, 183, 1009-1025. https://doi.org/10.1016/j.jenvman.2016.09.063

Chodijah,Siti, H., \& Liza,Novriani, F., Ida. (2018). Pengolahan Limbah Cair Kelapa Sawit Menggunakan Membran Berbasis Kitosan, PVA, dan Silika. Jurnal Penelitian Teknologi Industri, 9(2), 73. https://doi.org/10.33749/jpti.v9i2.3498

Dandil, S., Akin Sahbaz, D., \& Acikgoz, C. (2019). Adsorption of Cu(II) ions onto crosslinked chitosan/Waste Active Sludge Char (WASC) beads: Kinetic, equilibrium, and 
thermodynamic study. International Journal of Biological Macromolecules, 136, 668675. https://doi.org/10.1016/j.ijbiomac.2019.06.063

Dima, J. B., Sequeiros, C., \& Zaritzky, N. E. (2015). Hexavalent chromium removal in contaminated water using reticulated chitosan micro/nanoparticles from seafood processing wastes. Chemosphere, 100-111. https://doi.org/10.1016/j.chemosphere.2015.06.030

Evaani, D. Y., \& Cahyaningrum, S. E. (2012). Sintesis dan Pemanfaatan Kitosan - Alginat Sebagai Membran Ultrafiltrasi Ion K+. UNESA Journal of Chemistry, 1(2), 7.

Fatombi, J. K., Lartiges, B., Aminou, T., Barres, O., \& Caillet, C. (2013). A natural coagulant protein from copra (Cocos nucifera): Isolation, characterization, and potential for water purification. Separation and Purification Technology, 116, 35-40. https://doi.org/10.1016/j.seppur.2013.05.015

Feng, G., Ma, J., Zhang, X., Zhang, Q., Xiao, Y., Ma, Q., \& Wang, S. (2019). Magnetic natural composite Fe3O4-chitosan@bentonite for removal of heavy metals from acid mine drainage. Journal of Colloid and Interface Science, 538, 132-141. https://doi.org/10.1016/j.jcis.2018.11.087

Hameed, B. H., Mahmoud, D. K., \& Ahmad, A. L. (2008). Equilibrium modeling and kinetic studies on the adsorption of basic dye by a low-cost adsorbent: Coconut (Cocos nucifera) bunch waste. Journal of Hazardous Materials, 158(1), 65-72. https://doi.org/10.1016/j.jhazmat.2008.01.034

Huang, Yimin, Lee, X., Macazo, F. C., Grattieri, M., Cai, R., \& Minteer, S. D. (2018). Fast and efficient removal of chromium (VI) anionic species by a reusable chitosan-modified multi-walled carbon nanotube composite. Chemical Engineering Journal, 339, 259-267. https://doi.org/10.1016/j.cej.2018.01.133

Huang, Yong-hong. (2018). Comparison of rhizosphere and endophytic microbial communities of Chinese leek through high-throughput 16S rRNA gene Illumina sequencing. Journal of Integrative Agriculture, 17(2), 359-367. https://doi.org/10.1016/S20953119(17)61731-3

Hui, M., Shengyan, P., Yaqi, H., Rongxin, Z., Anatoly, Z., \& Wei, C. (2018). A highly efficient magnetic chitosan "fluid" adsorbent with a high capacity and fast adsorption kinetics for dyeing wastewater purification. Chemical Engineering Journal, 345, 556-565. https://doi.org/10.1016/j.cej.2018.03.115

Iqbal, J., Wattoo, F. H., Wattoo, M. H. S., Malik, R., Tirmizi, S. A., Imran, M., \& Ghangro, A. B. (2011). Adsorption of acid yellow dye on flakes of chitosan prepared from fishery wastes. Arabian Journal of Chemistry, 4(4), 389-395. https://doi.org/10.1016/j.arabjc.2010.07.007

Karimifard, S., \& Alavi Moghaddam, M. R. (2018). Application of response surface methodology in physicochemical removal of dyes from wastewater: A critical review. Science of The Total Environment, 640-641, 772-797. https://doi.org/10.1016/j.scitotenv.2018.05.355

Kim, M. K., Shanmuga Sundaram, K., Anantha Iyengar, G., \& Lee, K.-P. (2015). A novel chitosan functional gel included with multiwall carbon nanotube and substituted polyaniline as adsorbent for efficient removal of chromium ion. Chemical Engineering Journal, 267, 51-64. https://doi.org/10.1016/j.cej.2014.12.091

Kumari, S., \& Rath, P. K. (2014). Extraction and Characterization of Chitin and Chitosan from (Labeo rohit) Fish Scales. Procedia Materials Science, 6, 482-489. https://doi.org/10.1016/j.mspro.2014.07.062

Kumari, S., Rath, P., Sri Hari Kumar, A., \& Tiwari, T. N. (2015). Extraction and characterization of chitin and chitosan from fishery waste by chemical method. Environmental Technology \& Innovation, 3, 77-85. https://doi.org/10.1016/j.eti.2015.01.002 
Lasindrang, M., Suwarno, H., Tandjung, S. D., \& Kamiso, H. N. (2015). Adsorption Pollution Leather Tanning Industry Wastewater by Chitosan Coated Coconut Shell Active Charcoal. Agriculture and Agricultural Science Procedia, 3, 241-247. https://doi.org/10.1016/j.aaspro.2015.01.047

Lessa, E. F., Nunes, M. L., \& Fajardo, A. R. (2018). Chitosan/waste coffee-grounds composite: An efficient and eco-friendly adsorbent for removal of pharmaceutical contaminants from water. Carbohydrate Polymers, 189, 257-266. https://doi.org/10.1016/j.carbpol.2018.02.018

Li, N., Xiong, X., Ha, X., \& Wei, X. (2019). Comparative preservation effect of water-soluble and insoluble chitosan from Tenebrio molitor waste. International Journal of Biological Macromolecules, 133, 165-171. https://doi.org/10.1016/j.ijbiomac.2019.04.094

Liu, J., Liu, W., Wang, Y., Xu, M., \& Wang, B. (2016). A novel reusable nanocomposite adsorbent, xanthated Fe $3 \mathrm{O} 4$-chitosan grafted onto graphene oxide, for removing $\mathrm{Cu}(\mathrm{II})$ from aqueous solutions. Applied Surface Science, 367, 327-334. https://doi.org/10.1016/j.apsusc.2016.01.176

Lou, T., Cui, G., Xun, J., Wang, X., Feng, N., \& Zhang, J. (2018). Synthesis of a terpolymer based on chitosan and lignin as an effective flocculant for dye removal. Colloids and Surfaces A: Physicochemical and Engineering Aspects, 537, 149-154. https://doi.org/10.1016/j.colsurfa.2017.10.012

Ma, H., Pu, S., Ma, J., Yan, C., Zinchenko, A., Pei, X., \& Chu, W. (2018). Formation of multilayered chitosan honeycomb spheres via breath-figure-like approach in combination with co-precipitation processing. Materials Letters, 211, 91-95. https://doi.org/10.1016/j.matlet.2017.09.091

Markandeya, Dhiman, N., Shukla, S. P., \& Kisku, G. C. (2017). Statistical optimization of process parameters for removal of dyes from wastewater on chitosan cenospheres nanocomposite using response surface methodology. Journal of Cleaner Production, 149, 597-606. https://doi.org/10.1016/j.jclepro.2017.02.078

Markandeya, Dhiman, N., Shukla, S. P., Mohan, D., Kisku, G. C., \& Patnaik, S. (2018). Comprehensive remediation study of disperse dyes in wastewater using cenospheres nanosyntactic foam. Journal of Cleaner Production, 182, 206-216. https://doi.org/10.1016/j.jclepro.2018.01.244

Mohd Din, A. T., Hameed, B. H., \& Ahmad, A. L. (2009). Batch adsorption of phenol onto physiochemical-activated coconut shell. Journal of Hazardous Materials, 161(2-3), 1522-1529. https://doi.org/10.1016/j.jhazmat.2008.05.009

Nair, V., Panigrahy, A., \& Vinu, R. (2014). Development of novel chitosan-lignin composites for adsorption of dyes and metal ions from wastewater. Chemical Engineering Journal, 254, 491-502. https://doi.org/10.1016/j.cej.2014.05.045

Nitayaphat, W. (2017). Chitosan/coffee residue composite beads for removal of reactive dye. Materials Today: $\quad$ Proceedings, 4(5), 6274-6283. https://doi.org/10.1016/j.matpr.2017.06.127

Noralia, E., \& Dina Kartika, M. (2013). Filtration Metal Ion Cr6+ with Composite Chitosan Silica Membrane. UNESA Journal of Chemistry, 2(1), 5.

Novi, Y., Zaharah, T. A., \& Destiarti, L. (2016). Sintesis dan Karakterisasi Membran Komposit Kitosan-Kaolin. JKK, 5(4), 47-56.

Nuralam, Endoraza, P., \& Arbi, B. P. (2012). Pemanfaatan Limbah Kulit Kepiting Menjadi Kitosan Sebagai Penjernih Air Pada Air Rawa dan Air Sungai. Jurnal Teknik Kimia, $18(4), 7$.

Nurdin, F., Arifina, \& Maulana, A. (2016). Uji Kemampuan Kitosan Dan Selulosa Pada Proses Penjerapan Logam Fe dan Zn yang Terkandung dalam Limbah Oli Bekas dengan Metode Kolom Filtrasi. Analit: Analytical and Environmental Chemsitry, 1(01), 7. 
Nurdjannah, N. (2016). Penjernihan Sirup Pala dengan Chitosan dan Hemisellulase. J.Tek.Ind.Pert, 16(1), 1-8.

Phasuphan, W., Praphairaksit, N., \& Imyim, A. (2019). Removal of ibuprofen, diclofenac, and naproxen from water using chitosan-modified waste tire crumb rubber. Journal of Molecular Liquids, 294, 111554. https://doi.org/10.1016/j.molliq.2019.111554

Ramadhanur, S., \& Sari, A. M. (2015). Pengaruh Konsentrasi Khitosan dan Waktu Filtrasi Membran Khitosan Terhadap Penurunan Kadar Fosfat dalam Limbah Deterjen. Konversi, 4(1), 13.

Ruswahyuni Hartoko, Agus, R., Siti. (2010). Aplication of Chitosan for Water Quality and Macrobenthic Fauna Rehabilitation in Vannamei Shrimps (Litopenaeus Vannamei) Ponds, North Coast of Semarang, Central Java - Indonesia. Journal of Coastal Development, 14(1), 1-10.

Samuel, M. S., Bhattacharya, J., Raj, S., Santhanam, N., Singh, H., \& Pradeep Singh, N. D. (2019). Efficient removal of Chromium(VI) from aqueous solution using chitosan grafted graphene oxide (CS-GO) nanocomposite. International Journal of Biological Macromolecules, 121, 285-292. https://doi.org/10.1016/j.ijbiomac.2018.09.170

Shaida, Mohd. A., Dutta, R. K., \& Sen, A. K. (2018). Removal of diethyl phthalate via adsorption on mineral rich waste coal modified with chitosan. Journal of Molecular Liquids, 261, 271-282. https://doi.org/10.1016/j.molliq.2018.04.031

Sohni, S., Hashim, R., Nidaullah, H., Lamaming, J., \& Sulaiman, O. (2019). Chitosan/nano-lignin based composite as a new sorbent for enhanced removal of dye pollution from aqueous solutions. International Journal of Biological Macromolecules, 132, 1304-1317. https://doi.org/10.1016/j.ijbiomac.2019.03.151

Susanto, Joko Prayitno, P., teguh. (2000). Chitosan Sebagai Bahan Koagulan Limbah Cair Industri Tekstil. Jurnal Teknologi Lingkungan, 1(2), 121-125.

Susilowati, Endang, H., Sri, \& Mahatmanti, F. W. (2018). Sintesis Kitosan-Silika Bead sebagai Pengadsorpsi Ion Logam $\mathrm{Pb}(\mathrm{II})$ pada Limbah Cair Batik. Indonesian Journal of Chemical Science, 7(2), 9.

Utami, Umi Barorh Lili Irawati, Utami, M., Hanifa. (2011). Filtration of Sasirangan Wastewater Treatment Using Oil Palm Shell Active Charcoal Coated with Chitosan After Coagulation with FeSO4. Sains dan Terapan Kimia, 5(1), 34- 44.

Wahyuni, S., Siswanto, S., \& Putra, S. M. (2017). Formulasi Komposisi Membran Kitosan Dan Optimalisasi Pengadukan Dalam Penurunan Kandungan Padatan Limbah Cair Kelapa Sawit. Widyariset, 3(1), 35. https://doi.org/10.14203/widyariset.3.1.2017.35-46

Wang, K., Ma, H., Pu, S., Yan, C., Wang, M., Yu, J., Wang, X., Chu, W., \& Zinchenko, A. (2019). Hybrid porous magnetic bentonite-chitosan beads for selective removal of radioactive cesium in water. Journal of Hazardous Materials, 362, 160-169. https://doi.org/10.1016/j.jhazmat.2018.08.067

Yan, Y., Yuvaraja, G., Liu, C., Kong, L., Guo, K., Reddy, G. M., \& Zyryanov, G. V. (2018). Removal of $\mathrm{Pb}(\mathrm{II})$ ions from aqueous media using epichlorohydrin crosslinked chitosan Schiff's base@Fe 3 O 4 (ECCSB@Fe 3 O 4 ). International Journal of Biological Macromolecules, 117, 1305-1313. https://doi.org/10.1016/j.ijbiomac.2018.05.204

Yang, S., Okada, N., \& Nagatsu, M. (2016). The highly effective removal of Cs + by low turbidity chitosan-grafted magnetic bentonite. Journal of Hazardous Materials, 301, 8-16. https://doi.org/10.1016/j.jhazmat.2015.08.033

Yavuz, A. G., Uygun, A., \& Bhethanabotla, V. R. (2009). Substituted polyaniline/chitosan composites: Synthesis and characterization. Carbohydrate Polymers, 75(3), 448-453. https://doi.org/10.1016/j.carbpol.2008.08.005 
Zhang, W., Zhang, S., Wang, J., Wang, M., He, Q., Song, J., Wang, H., \& Zhou, J. (2018). Hybrid functionalized chitosan-A12O3@SiO2 composite for enhanced $\mathrm{Cr}(\mathrm{VI})$ adsorption. Chemosphere, 203, 188-198. https://doi.org/10.1016/j.chemosphere.2018.03.188

Zulfi, F., Dahlan, K., \& Sugita, P. (2014). Karakteristik Fluks Membran Dalam Proses Filtrasi Limbah Cair Industri Pelapisan Logam. Jurnal Biofisika, 10(1), 11. 